Araştırma Makalesi

Research Article

\title{
Uluslararası Politik Ekonomi: Bitmeyen Kırım Sorunu
}

\author{
International Political Economy: \\ Unending Problem of Crimea
}

Güvenlik Stratejileri

Y1l: 13

Sayı: 26

$\ddot{O}_{z}$

Uluslararast Politik Ekonomi (UPE); devletlerin, ekonomik ajanlartn, uluslararası örgütlerin karşıllılı etkileşimlerini çıkar ve çatışma olguları üzerinden yorumlamaya çalışmaktadır. Bu yorumlamayı yaparken de ortaya çıkan sonuçların uluslararası hukuk sistemine uygunluğu test edilmektedir. Bu testin sonucunda ortaya "meşruiyet" sorunu çıkmaktadır. "Yasallık" kavramindan ayrlan "meşruiyet" uluslararası hukukun da sorgulanmasina neden olmaktadır. Ancak UPE'nin ilgilendiği ve açıklamaya çalıştığı bir konu olan devletlerin ekonomik çıkar ve kaygları, uluslararası hukukta meydana gelen bu sorunların kimi zaman göz ardı edilmesine kimi zaman da gündeme getirilmemesine yol açmaktadır. Başka bir deyişle, uluslararası hukuktaki bu ikilemin ortaya çıkmasina da genellikle devletlerin ekonomik ve politik çıkarlarının bir ahenge dönüşı̈̈̆ğ politik ekonomi perspektifleri sebep olmaktadır. Bu çalışmada uluslararası hukukun UPE bağlamında kısa bir değerlendirmesi yapılarak ve Ukrayna-Kırım Krizi üzerinden ekonomik kaygılar göz önünde bulundurularak mevcut uluslararası sistem tartışlacaktır.

Anahtar kelimeler: Uluslararası Politik Ekonomi, Kırım, Uluslararası Hukuk, Meşruiyet, Enerji.

\footnotetext{
* Yrd. Doç. Dr., Marmara Üniversitesi Uluslararası Politik Ekonomi Anabilim Dalı Başkan1, e-posta: arzu.al@marmara.edu.tr.

** Öğ. Gör., Altınbaş Üniversitesi MYO Dış Ticaret Bölümü, e-posta: figen.ayvaci@ altinbas.edu.tr.
}

Geliş Tarihi / Received : 24.08.2017 Kabul Tarihi / Accepted : 17.10.2017 
222

Güvenlik

Stratejileri

Y11: 13

Sayı: 26

Abstract

The International Political Economy (IPE) tries to interpret the mutual interactions of states, economic agents, international organizations by revealing over the cases of conflicts and interests. During this interpretation, the results are tested for compliance with the international legal system. As a result of this test, "legitimacy" problem arises. "Legitimacy", separated from the concept of "legality", causes international law to be questioned. However, the economic interests and concerns of the states, in which the IPE is interested and which it tries to explain, are sometimes leading to ignore these problems in international law. In other words, the emergence of this dilemma is often caused by the political and economic perspectives of the states which are transformed into a harmony. In this study, an evaluation of the international law in the context of IPE will be presented shorthly and the current international system over the UkraineCrimean Crisis will be discussed in view of economic concerns.

Keywords: International Political Economy, Crimea, International Law, Legitimacy, Energy.

\section{Giriş}

Uluslararası Politik Ekonomi (UPE); Robert Gilpin'in söylemi ile devletlerin, çokuluslu şirketlerin ve diğer güçlü aktörlerin uluslararası sistemin doğasını etkilemek için güçlerini nasıl kullandıklarını; yani ekonomi ve politika arasındaki etkileşimleri ifade etmektedir. ${ }^{1}$ Başka bir ifadeyle, gücün izinden giderek zenginliği biriktirmek için kullanılan bir yöntemdir. Geniş anlamıyla ise UPE; tarih içerisinde ve değişik coğrafi bölgelerde devletler, piyasalar ve toplumlar arasındaki sürekli değişen ilişkileri daha doğru şekilde tanımlayabilmek ve açıklayabilmek için kendinden önceki disiplinlerin analiz metotlarını bir araya getirmektedir. ${ }^{2}$ Devletlerin uluslararası ilişkilerdeki reaksiyonlarının arka planında hem siyasi, hem hukuki, hem de ekonomik gerekçeler yatmaktadır. Öte yandan, UPE'ye göre, her siyasal çabanın bir

${ }^{1}$ Robert Gilpin, Global Political Economy : Understanding The International Economic Order, Princeton University Press, 2001, New Jersey, s. 78.

${ }^{2}$ David N. Balaam ve Bradford Dillman, Uluslararası Ekonomi Politiğe Giriş, (çev. Nasuh Uslu), Adres Yayınları, 2016, Ankara, s. 32. 
ekonomik gerekçesi bulunabileceği gibi, her ekonomik girişimin de bir siyasal yansıması olabilecektir. ${ }^{3}$ Ancak bu girişimlerin sınırları uluslararası hukuk tarafından çizilmiştir.

Gilpin'in "Gücün izini sürmek ve zenginliği biriktirmek" tanımlamasından yola çıkacak olursak, uluslararası düzende hukuki ve siyasi krizlerin ortaya çıkmasının temel nedenini, gücü elinde bulunduran devletlerin daha zengin ve daha güçlü olma arzusu olarak açıklayabiliriz. $\mathrm{Bu}$ istek devletleri, özellikle ekonomik gerekçelerle uluslararası hukukun dışına çıkarak hareket etmeye itmektedir. UPE'de realist görüşe göre rasyonel ajanlar olan devletler, yetenekleri ya da kapasitelerinin birikimi ile güç fonksiyonlarının maksimize edilmesine yönelik hareket etmektedirler. Rakipleri üzerinde daha fazla etkiye sahip olmak isteyen devlet, bu gücünü test etmekten çekinmemektedir. ${ }^{4}$ Güç ise, Nye'nin deyimiyle, "Uluslararası poker oyununda büyük kartları elinde tutmak", anlamına gelmektedir. Ayrıca bir devleti güçlü kılan öğeleri aşağıdaki gibi sıralayabiliriz: ${ }^{6}$

$\checkmark$ Askerî güç: savunma sektörünün varlığı, silah üretimi ve ticareti, askerî kapasite.

$\checkmark$ Sahip olunan nüfus kütlesi.

$\checkmark$ Ekonomisinin gücü ve ağırlığı, ileri teknoloji ile üretilen mal ve hizmet, büyük stratejik piyasaların kontrolü (petrol ve finans).

İște bu faktörlerin gücü göz önüne alındığında; uluslararası ilişkilerde devletler farklı pozisyonlar almakta, bazen sistemin sınırlarını zorlamakta, bazen de bu sınırı aşmaktadır. Hatta günümüzde devletler mevcut uluslararası sistemi değiştirebilecek adımlar

\footnotetext{
3 Arzu Al, "Politika-Ekonomi Kesişmesi: Yeni Bir Bilim Dalı Olarak Uluslararası Politik Ekonomi”, IG G̈̈SBD, 2015, Cilt: 2, Sayı:1, 143-159, s. 147.

${ }^{4}$ Mehdi Abbas, "L'Économie Politique Internationale entre Théories et Histoire", Recherches Internationaless, 2010, Say1:88, 47-72, s. 54.

5 Joseph S. Nye, Soft Power: The Means to Success in World Politics, Public Affairs, 2004, New York, s. 3.

${ }^{6}$ Grégory Vanel, "Le Concept d'Hégémonie en Économie Politique Internationale", Cahier de Recherche - CEIM, Université de Qubec, 2003, s. 11, http://www.ieim.uqam.ca/ IMG/pdf/Cahier_Vanel.pdf (Erişim Tarihi: 18.10.2017).
}

223

Güvenlik Stratejileri

Y11: 13

Say1: 26 
224

Güvenlik Stratejileri

Y1l: 13

Sayı: 26 atmaktadır. Geçmiş yüzyıl bize uluslararası sistemin savaşlar ya da ekonomik krizler nedeni ile değişikliklere uğradığını göstermektedir. Günümüz dünyasında ise bu değişikliklerde rol oynayan devletlerin reaksiyonlarının tamamı için Uluslararası Politik Ekonomi (UPE) kavramı kullanılmaktadır. Başka bir ifadeyle, ekonominin ve politikanın dengeli bir şekilde işlemesini sağlayan UPE perspektifinden bakıldığında, devletler kendi ekonomik ya da siyasi çıkarları için yasal olmayan durumlara hemen uluslararası hukukun öngördüğü yaptırımları uygulamamakta ya da askerî güç kullanarak daha da ilerisine gidebilecekken bu seçeneği kullanmamaktadırlar. Örneğin 2014 yılında Rusya'nın Kırım'ı ilhakı ile sonuçlanan Ukrayna krizi, UPE açısından örnek teşkil etmektedir. Ukrayna ve Kırım gibi birincil aktörlerin yanı sıra; Avrupa Birliği (AB), Rusya, Amerika Birleşik Devletleri (ABD) ve Kuzey Atlantik Antlaşması Örgütü (NATO) gibi ikincil aktörlerin de yer aldığı bu sorun karşısında $A B$ ve Rusya, kendi çıkarlarına büyük zararlar vermeyecek ölçüde hareket etmiştir. Ukrayna krizi esnasında $\mathrm{AB}$ tarafından Kırım'ın Rusya'ya katılmasının yasa dışılığı öne sürülerek ekonomik yaptırımlar uygulanmaya başlanmış; Rusya ise dünya kamuoyuna Kırım nüfusunu ve yapılan referandumu öne sürerek meseleyi meşruiyet açısından ele almıştır. Kırım meselesinin temelinde uluslararası hukuk açısından self determinasyon hakkı (kendi kaderini belirleme hakkı) çerçevesinde tepki ve savunmalar yapılmıştır. Ancak self determinasyon ilkesinin bir hak olarak savunulabilmesi için bu hakkın meşru bir temele dayanması gerekmektedir. Çünkü kullanılmak istenen hak, uluslararası hukukun kural ve ilkelerine uygun ise gerçekten bir haktan bahsedilebilir.

"Yasallık" ve "Meşruiyet" ikilemi arasında kalan Kırım meselesi; $A B$ ve Rusya'nın birbirlerinin gücünü test etmeleri açısından da bir firsat sunmuştur. Doğu Avrupa'daki güç mücadelesinde hangi tarafin kazanacağından çok, tarafların hangi ölçülerde kazançlı çıkacağı, $A B$ ve Rusya'nın asıl odaklanması gereken konudur. Çünkü $A B$ 'nin enerji konusunda Rusya'ya olan bağımlılığı ve Rusya'nın en büyük enerji pazarının $\mathrm{AB}$ olması bu iki tarafı birbirine bağımlı kılmıştır. Böylelikle yaptırımlar ve çatışma sürecini bir tarafın yok oluşuna odaklamak; bir tarafi değil, her iki tarafi da yok etmeye yetecektir. 
Öte yandan, uluslararası sistemde yumuşak güç kullanımı da artmakta ve bu da meşruiyet arama baskısı yaratmaktadır. Yumuşak güç kullanarak devletlerin başarıya ulaşması, kamuoyunda bu şekilde de hedeflere ulaşılabildiği algısını oluşturmakta ve konvansiyonel savaşlarla bir şeyler elde etmek eskiye nazaran daha fazla kabul edilmez hâle gelmektedir. Yumuşak güç modeli, gelişmekte olan ekonomilere veya onların rekabet otoritelerine kurallar, ilkeler veya standartlar koymaktan çok taraflı iş birliğinin baskın şekli hâline gelmiştir. ${ }^{7}$ Ancak özellikle uluslararası ekonomide yumuşak gücün yasal açıdan etkili olmasının önündeki en büyük engel, Kuzey ve Güney ülkeleri arasındaki ulusal çıkar çatışmalarından kaynaklanan siyasi endişeler olarak karşımıza çıkmaktadır. ${ }^{8}$ Rusya ve Ukrayna örneğinde ise, Kırım'ın ilhakından sonra $\mathrm{AB}$ 'nin sert güç kullanmaması, Rusya'nın işgaline ekonomik ambargolarla yanıt vermesi, yine çıkar tabanlı ekonomik endişelerden ileri gelmektedir. Yumuşak güç kullanımının her geçen gün arttığı ve ülkeler arasındaki ilişkilerde ön plana çıkarak etkisinin uzun sürdüğü açikça görülmektedir.

Günümüzde Rusya'nın sahip olduğu enerji gücü, tek başına bir "güç" olarak düşünülmemektedir. Daha açık bir ifadeyle, ülkenin de başlı başına bir markaya dönüşmesi ya da bir marka değerinin olması gerekmektedir; çünkü bu durum ülkelere karşı uluslararası bir kabul kazandırmaktadır. Bu noktada uygulanabilecek en önemli yol, kamu diplomasisinden geçmektedir. Kamu diplomasisinin bugün en moda uygulama alanlarından biri olan yumuşak güç uygulaması ile orta ölçekli devletler küresel yönetişimde kendilerine alan açabilmekte, yabanc1 kamuoyuna seslerini duyurabilmektedir; ancak Rusya gibi ülkelerin işi daha zor olmaktadır. Tarihten gelen uluslararası önyargıyı

\footnotetext{
${ }^{7}$ Cross-Border Merger Control: Challenges for Developing and Emerging Economies, s. 17, OECD, http://www.oecd.org/competition/mergers/50114086.pdf (Erişim Tarihi: 18.10.2017).

${ }^{8}$ Huei-Chih Niu, "The Role of International Economic Soft Law in the North-South Economic Relations", s. 36, http://mx.nthu.edu.tw/ honiu/paper/200004.pdf (Erişim Tarihi: 18.10.2017).
}

225

Güvenlik Stratejileri

Y11: 13

Say1: 26 
226

Güvenlik

Stratejileri

Y1l: 13

Say1: 26 yıkmak ya da yumuşak gücün tersi olan sert gücü kullanan ve her an kullanma potansiyeline sahip olan bir ülke imajını yıkmak kolay olmayacaktır. Zaten Rusya'nın böyle bir arzusunun olup olmadığı da sorgulanmaktadır. Yumuşak gücü ilk olarak Joseph Nye tanımlamıştır ve Nye, yumuşak güç "tercih edilen sonuçlara ulaşmak için gündemi çerçeveleyen ortak seçilmiş araçlar vasıtasıyla başkalarını etkileme yöntemidir" demiştir. ${ }^{9}$ Bu tanımlama üzerinden açıklamak yapacak olursak Rusya'nın da Kırım halkını etkileyerek kendisine katılımını sağladığı açıktır. Ukrayna'nın rızası dışında davranmasına rağmen Kırım'da referandumun yapılması, Rusya için bir rıza almış olma imajı çizmektedir. Elbette referandumun bir oldu-bitti havasında olması ve uluslararası arenada da kabul görmemesi, uluslararası hukuk tarafindan da tanınmamasına gerekçe olmuştur.

Görüldüğü üzere, Kırım konusu “yasallık” ve "meşruiyet" zemininde tartışılırken, sunulan çözümün aynı zamanda meşru kabul edilebilmesi için yumuşak güç kullanımı önemli bir faktör olmaktadır. "Yumuşak güç", "yasallık", "meşruiyet kazandırma" gibi uluslararası sistemin bütün bu araçları, aynı zamanda uluslararası politik ekonominin de etkin kullandığı araçlardır. Çünkü uluslararası politik ekonomi elde edilmek istenilen çıkarlara yönelik bu araçları kullanırken siyaset ve ekonomi dengesini de kurarak ulaşmayı hedeflemektedir. Meşruiyet ise bu dengenin kurulmasını sağlamaya yönelik bir hareket alanı sunmaktadır. $\mathrm{Bu}$ açıklamalar 1şığında, makalemizin amacı; uluslararası politik ekonominin ve uluslararası hukukun kesiştiği noktada bulunan ve bir türlü bitmek bilmeyen Kırım sorununu hem siyasi, hem de güncel ekonomik veriler ile analiz ederek açıklamaktır. Bu amaç doğrultusunda öncelikle "Politik Ekonomi ve Hukuk: Meşruiyet Sorunu" başlı̆̆ altında ele alınarak aralarındaki ilişkinin kuvveti ve dengesi açıklanacak; "Kırım Sorununda Devletlerin Politik Ekonomisi Bağlamında Meşruiyet Yaklaşımları" başlığı altında da bu yaklaşımı hangi gerekçeler doğrultusunda benimsedikleri hakkında bilgiler verilecektir. Sonrasında

${ }^{9}$ Joseph S. Nye, Soft Power: The Means to Success in World Politics, Public Affairs, 2004, New York, s. 3. 
ise bazı ülkelerin Kırım krizine farklı politik ekonomi yaklaşımlarına vurgu yapılacak, bunu yaparken de özellikle güncel ekonomik veriler kullanılacaktır. Ayrıca makalemiz, genel bir değerlendirme ve Kırım sorununun geleceği hakkında açıklamalar yapılarak sonuçlandırılacaktır.

\section{Politik Ekonomi ve Hukuk: Meşruiyet Sorunu}

21'inci yüzyılda çok kutuplu bir dünyaya geçişin sancıları sürerken ülkelerin politik ekonomileri zaman zaman uluslararası hukuk düzeni ile çatışmakta ve meşruiyet sorunu ortaya çıkmaktadır. Uluslararası hukuk bildiğimiz klasik tanımıyla; egemen devletler arasındaki ilişkileri ve hatta devletler ile uluslararası örgütler arasındaki ilişkileri yöneten evrensel kural ve ilkeler sistemidir. Ancak, genel kabul gören tanımının arka planında kalan anlamı göz önüne alındığında, uluslararası hukukun amacı; diğer hukuk sistemlerinde olduğu gibi uluslararası ilişkileri düzenleyerek anlaşmazlıkları önlemek ve engellemek için yardımcı olmanın dışına taşmıştır. Yani uluslararası hukukun önemli bir kısmı, anlaşmazlık çözümü ile değil; anlaşmazlıklardan kaçınmakla ilgilenerek uluslararası ilişkilerin gündelik düzenlemesine odaklanmaktadır. ${ }^{10}$ Özetlemek gerekirse, olayların yasallık çerçevesinde gelişip gelişmediğinin irdelenmesinden ziyade, olaylara nasıl meşruiyet kazandırılacağı ile ilgilenilmektedir. "Meşruiyet", "yasallık”tan daha geniş bir kavram olarak karşımıza çıkmaktadır. Yasallık hukuki olup olmamakla doğrudan ilişkilidir; ancak meşruiyet hukuki bir dayanak olmaksızın da elde edilebilmektedir. Bir durumun hem meşru, hem de yasal olması ideal olanı temsil ederken; pratikte her durum hem yasal, hem de meşru olmayabilir. Yani her yasal durum meşru sayılmazken, meşru görülen her durum da yasal olmayabilir. Örneğin ABD'nin 2003 yılında Irak'a olan müdahalesi hem yasa dışı, hem de gayrimeşru olarak kabul edilmektedir. 2003'ten önce ABD'nin Irak'a uygulamı̧ olduğu ambargo ise yasal kabul edilirken meşru görülmemiştir. 1999 yılında Kosova'ya yapılan müdahalenin yasallığı ise tartışmalı olarak

${ }^{10}$ S. Blay vd., In Public International Law: An Australian Perspective, Oxford University Press, 2005, Oxford, s. 3. 
228

Güvenlik Stratejileri

Y1l: 13

Sayı: 26

kabul edilirken, meşru sayılmaktadır. ${ }^{11}$ Nitekim bir kurumun veya düzenlemenin meşruluğunun sağlanması için gerekli şartlar, yasallık için gerekli kurallardan daha fazla olabilmekte ve ahlak, etik, politik, hümanizm gibi şartlar aranmaktadır. Yani bir yasal sistemin meşruiyeti, yalnızca pozitif yasa perspektifinden geçerliliğine bağlı değil; aynı zamanda birçok objektif veya sübjektif faktörün de değerlendirmeye tabi olmasından kaynaklanmaktadır. Devletler arasında çıkan uluslararası siyasi ve hukuki krizler de yasallık zemininden ziyade meşruiyet zemini üzerinden tartışılmaktadır. $\mathrm{Bu}$ şekilde yürütülen tartışma, gücü elinde bulunduranlara daha esnek ve göreceli bir alanda hareket edebilme kabiliyeti kazandırmaktadır. Başka bir ifade ile meşruiyet; devletlerin politik ekonomilerine hizmet edecek kararların oluşması için ortaya çıkan bir çabadan daha fazlası değildir. Günümüzde ortaya çıkan uluslararası hukuki krizler de bu alan içinde tartışılmakta, çözüme ulaştırılmaya çalış1lmakta ve çözümsüzlük hâlinde bekletilmektedir. Makalemizde vaka çalışması olarak ele alacağımız Kırım sorunu, AB ve Rusya arasındaki politik ekonomik menfaatlerin çatışmasının tam ortasında bulunmaktadır. AB ve Rusya arasındaki enerji bağımlılığı konusunda Kırım jeopolitik açıdan önem arz etmektedir. Bölge Rusya'nın Avrasyacı politikası ile ABD'nin üstlendiği Atlantikçi politika arasında önemli bir konuma sahiptir.

\section{Kırım Sorununda Devletlerin Politik Ekonomisi Bağlamında Meşruiyet Yaklaşımları}

Ukrayna'ya bağlı olan Kırım Özerk Cumhuriyeti'nin Rusya tarafindan ilhakının uluslararası hukuka uygun olup olmadığı tartışmalı bir hâl almıştır. Kırım'ın ilhakının uluslararası hukuki kriz olarak ortaya çıkmasının en önemli nedeni; halkların kendi geleceğini belirleme ilkesi olan self determinasyon ilkesinin yanlış bir şekilde yorumlanarak uygulanmış olmasıdır. Çünkü bu, Ukrayna'nın isteği dışında gelişmiş bir durumdur ve direkt olarak bir ülkenin toprak bütünlügünü bozmaya

${ }^{11}$ Vesselin Popovski and Nicholas Turner, "Legality and Legitimacy in International Order, Policy Brief”, Policy Brief, United Nations University, Say1: 5, 2008, s. 1. 
yönelik olarak ortaya çıkmışırı. Öte yandan, Kırım meselesinde self determinasyon ilkesinin işleyebilmesi için gerekli olan işgal veya sömürge halkı olma gibi bir durum da söz konusu değildir. Uluslararası hukukun işleyişine yönelik Kırım'ın Rusya'ya katılımını meşrulaştırmaya çalışan çelişkili yaklaşımlarla da uluslararası bir kriz hâline dönüşmüştür. Bugünkü uluslararası sistemin kurucusu olan Westphalia paradigmasının egemen ulus devlet anlayışı da uluslararası hukukun devletler karşısında zayıf kaldığını ortaya koymaktadır ve uluslararası hukukun yasal otoritesini dışlamaktadır. ${ }^{12} \mathrm{Bu}$ durum ise uluslararası hukuki krizlerin ortaya çıkmasına zemin hazırlamaktadır. Nitekim Rusya'nın Ukrayna'y1 işgali ile başlayan Kırım sorunu, ilerleyen süreçte uluslararası bir krize dönüşmüştür. $\mathrm{Bu}$ krizin arka planında ise bir güçler çekişmesinin yattığı açıç̧a görülmektedir. Daha açık bir ifadeyle, bir tarafta Rusya'nın ekonomik ve siyasal olarak güçlenme çabaları, diğer tarafta ise Avrupa ve ABD'nin bu çabaların önüne geçme arzusu mevcuttur. Avrasyacı politika ile Atlantikçi politikanın çatışmasından ibaret olan Kırım sorununun şekillenmesine ise $A B$ ve Rusya arasındaki enerji temelli ekonomik kaygilar sebep olmaktadır.

\section{Kırım Sorununun Arka Planı}

Kırım Sorunu denildiğinde meselenin Kırım'ın kendisi olduğu düşünülse de, bu konunun asıl nedeninin Ukrayna olduğu açıkça görülmektedir. Ukrayna özelinde uygulanan Rus yayılmacıllğı, Avrupa entegrasyonunun rakibi olan Avrasya Birliği projesinin bir parçasıdır. Beyaz Rusya, Kazakistan ve Ermenistan gibi ülkeler oluşturulabilecek bir Avrasya Birliği'ne katılmayı şimdiden kabul etmiştir. Buradaki amacın Rusya'nın, eski Sovyetler Birliği (SSCB) topraklarının kontrolünü yeniden kazanmasına izin vermek olduğu söylenebilir. 1997 yılında ABD'li siyaset bilimci Zbigniew Brzezinski "Ukrayna olmadan Rusya bir Avrasya İmparatorluğu olmaktan çıkar" "13 açıklamasını yapmıştır.

\footnotetext{
${ }^{12}$ Joel P. Tractman, "The Crisis of International Law", Case Western Reserve Journal of International Law, Cilt: 44, Say1: 1, 407-420, s. 409.

${ }^{13}$ Zbigniew Brzezinski, The Grand Chessboard, New York, 1997, s. 46.
} 
230

Güvenlik

Stratejileri

Y1l: 13

Sayı: 26

Bu açıklamadan da anlaşılacağı üzere, Rusya Avrasya İmparatorluğu kurma iddiasının peşinden gitmektedir. Hatta bu iddiasını Rusya'nın uluslararası siyasi manevralarını kısitlayan en büyük sorunu olan ekonomisinin kötü gidişatına rağmen sürdürmektedir. Büyük Avrasya İmparatorluğu kurmayı amaçlayan ve Rus kimliğinin varlığını da böyle bir ideale bağlayan Rusya, bu içinden çıkılmaz ekonomik sorununa rağmen, Kırım örneğinden de anlaşıldığ keskin adımlar atmaya başlamıştır.

Rusya'nın sıcak denizlere inme isteğini gerçekleştirme konusunda kritik bir önem taşıyan Kırım meselesinin vuku bulması, Ukrayna'da ortaya çıkan ayaklanmalara dayanmaktadır. Ukrayna içinde özerk bir cumhuriyet olan Kırım, kendi parlamentosuna sahip olmuştur. $\mathrm{Bu}$ parlamentonun ve hükümetinin Rusya yanlısı olması, yapılan atamaların da Ukrayna'nın başkenti Kiev'de gerçekleştirilmesi ortaya bir meşruiyet sorunu çıkarmıştır. Nitekim Kasım 2013'te muhalefetin başkent Kiev'in merkezindeki Bağımsızlık Meydanı'nda yaptığı gösteriler, bir olaylar silsilesinin fiilen başlamasına neden olmuştur. Ayrıca dönemin Ukrayna Cumhurbaşkanı Viktor Yanukoviç'in, Avrupa Birliği ile yapılacak ortaklık anlaşmasını imzalamak yerine, Rusya ile iş birliği yapma kararı alması gerilimi daha çok tırmandırmış; bu kararı protesto eden göstericilerin bir süre sonra polis müdahalesiyle karşılaşmasına neden olmuştur. Direnişi bastıramayan ve süreci yönetemeyen Yanukoviç; her ne kadar yönetim süresinin sonlarında muhalefetle bir uzlaşı metni imzalasa da, yaşanan olaylar nedeniyle meşruiyetini kaybederek 22 Şubat 2014'te ülkeyi terk etmiştir. Bu olayın akabinde Ukrayna Parlamentosu, cumhurbaşkanını azlederek geçici bir hükümet oluşturmuştur. Nitekim bu yeni oluşum, iktidarın tam anlamıyla değiştiğini tescil etmiştir. Kiev'deki siyasi kriz aşılmaya çalış1ırken, Rusya'nın beklenmedik bir şekilde Kırım yarımadasına özel kuvvetlerini çıkararak kontrolü ele geçirmesi, 27 Şubat 2014 tarihine damgasını vurmuştur. Yaşanan bu olay, durumu ülke içi bir krizden bölgesel ve uluslararası bir soruna dönüştürmüştür. ${ }^{14}$

${ }^{14}$ Vügar İmanbeyli, “Ülke-İçi Krizden Uluslararası Soruna Ukrayna-Kırım Meselesi”, 
Süreç her ne kadar çok hızlı ilerlemiş olsa da, aslında bir işgal söz konusudur. Günümüzde milletlerarası hukuk esasları göz önüne alındığında, işgal ile toprak kazanmanın meşru bir yanının olmadığı açıkça görülmektedir. Çünkü bir ülkenin işgal yoluyla kazanılabilmesi için bu ülkenin sahipsiz olması ya da başka bir devletin egemenliğine tabi olmaması gibi koşulların var olması gerekmektedir. ${ }^{15}$ İşgalin meşru olmadığı uluslararası hukuk çerçevesinde bu kadar açıkken; Kırım'da etnik olarak Rus kökenli silahlı milis grupları, önce Kırım Parlamentosu ile hükümet binalarını ve havalimanını işgal etmiş, ardından da söz konusu binalara Rus bayrağı çekmiştir. Bu olayları takip eden süreçte Rusya; Kırım'daki Rus etnik kökenli kişilere pasaport dağıtmaya başlamıştır. Pasaport dağıtımıyla birlikte ulaşılmak istenen hedefin, Güney Osetya'da olduğu gibi Rusya'nın kendi vatandaşlarını korumak için müdahale ettiği yönünde haklı bir hukuki sebep oluşturma arayışı olduğu söylenebilir. ${ }^{16}$ Ancak 1976' da İsrail'in Uganda müdahalesinde açıkça ortaya çıkmıştır ki, kendi halkını koruma gerekçesi ile meşru müdafaa hakkı kazanılamamaktadır. Her ne kadar İsrail Birleşmiş Milletler (BM) nezdinde ABD'nin engellemeleri nedeni ile kınanamamış olsa da; bu durum İsrail' in Uganda'ya askerî operasyon düzenlemesinin hukuki dayanağının olmadığı gerçeğini değiştirememiştir. Bu gerçek tarihte bir örnek ve emsal olarak yer etmiştir; ancak Rusya'nın özellikle Kırım konusunda harekete geçmesinin önü alınamamıştır. Bu tartışmalar bir tarafta sürerken Kırım Özerk Cumhuriyeti Meclisi referandum kararı alarak, kendi geleceğini belirleme yolunu seçmiştir. Önce bağımsız olan Kırım, daha sonra Rusya'ya katıldığını ilan etmiştir. Yaşanan olaylar sonucunda ise pek çok açıdan uluslararası hukuka aykırı yöntemlerle gelişen bu durum ortaya çıkmıştır. Bu noktada aklımıza şu soru gelmektedir: "Kırım neden bu kadar önemlidir?" Jeopolitik konumunu incelediğimizde Kırım; AB ve Rusya arasında

SETA Perspektif, Mart 2014, Say1: 36, Mart 2014, s. 1.

${ }_{15}$ İlyas Doğan, Devletler Hukuku, Astana Yayınları, Ankara, 2016, s. 267.

${ }^{16}$ Ahmet Hamdi Topal, "Kırım İşgali ve Uluslararası Hukuk Krizi (Kırım Krizini Nasıl Okumal1?)", D̈̈BAM, Mart 2014, 29-33, s. 29. 
232

Güvenlik Stratejileri

Y1l: 13

Say1: 26

tampon bir bölge olması nedeniyle önem arz etmektedir. Ayrıca değişmekte olan uluslararası düzenin öncü simgelerinden olan Kırım, Rusya'nın kendisine karşı tehdit olarak algıladığı NATO'ya karşı bir nevi güç gösterisi olmuştur. Çünkü Rusya NATO'nun kendi sınırlarına kadar dayanmasını ve bu yönde bir politika gütmesini uzunca bir zamandır eleştirmektedir. Rusya Devlet Başkanı Vladimir Putin'in 10 Şubat 2007'de Almanya'da düzenlenen 43'üncü Münih Güvenlik Konferansı'nda yaptı̆̆ konuşmada bu eleştiri en üst perdeden dile getirilmiştir. Putin'in ABD ile NATO'yu eleştirdiği konuşma; dünya gündeminde oldukça büyük bir yankı bulduğu gibi, tek kutuplu dünya düzenine yönelik eleștirisi özellikle Üçüncü Dünya ülkelerinden büyük destek almıştır. ${ }^{17}$ Kurım'ın ilhakı ise Putin'in bu konferansta tek kutuplu yönetimin bitmesi gerektiği çağrısının ardından, tek kutuplu düzeni resmî olarak bitiren bir vaka olarak tarihe geçmiştir. Sonuç olarak da Kırım bir uluslararası krize dönüşmüştür.

BM Genel Kurulunun 68/262 Sayılı Kararı, 2014 yılında gerçekleştirilen Kırım referandumunu geçersiz ilan ederek şu ifadeyi kullanmıştır: "Kırım Özerk Cumhuriyeti ve Sivastopol şehrinin statüsünde yukarıda belirtilen referandum temelinde herhangi bir değişikliği tanımak ve böyle değişmiş bir statünün tanınması olarak yorumlanabilecek herhangi bir işlem veya muameleden kaçınmak için tüm devletlere, uluslararası kuruluşlara ve uzmanlaşmış ajanslara çağrıda bulunur. " ${ }^{\prime 18} \mathrm{Bu}$ karara 100 üye devlet katılmıştır ve kararın esasta bağlayıcılığı yoktur. Doğal olarak bu durum, sadece var olan krizin yanına bir de çözümsüzlük eklemiştir. Nitekim referandum, bağımsızlık ilanı ve Rusya'ya katılım gibi sayabileceğimiz birçok konu ayrı ayrı başlıklar altında meşruiyet sorunları içermektedir. Ancak bu şeklî problemlerden ziyade, Kırım'ın uluslararası bir kriz olmasının

${ }^{17}$ Hasan Kavuncu ve Sibel Dilan, “21. Yüzyıl Eşiğinde Yeni Çelişkiler: Yeni Krizler Ortamında Uluslararası Siyasal Sistemin Çok Kutupluluğa Doğru Evrilmesi”, C.Ü. İktisadi ve İdari Bilimler Dergisi, Cilt: 17, Say1: 1, 2016, 945-953, s. 952.

${ }^{18}$ Resolution adopted by the General Assembly on 27 March 2014, http://www.un.org/ en/ga/search/view_doc.asp?symbol=A/RES/68/262 (Erişim Tarihi: 18.10.2017). 
temelinde üç ayrı gücün menfaatlerinin yattığını söylemek yanlış olmayacaktır. Bu üç büyük gücü aşağıdaki gibi sıralayabiliriz:

$\checkmark$ ABD: Ukrayna'yı tampon bölge olarak kullanan Atlantikçi politikanın Rusya'nın Ukrayna'dan koparıp aldığı Kırım konusunda sessiz kalması düşünülemezdi. Çünkü Rusya'ya istediğini vermek uluslararası hukukun ihlal edilmesine sessiz kalmak anlamına gelmekte ve gelecekte Rusya'nın başka neyi hukuk dışı olarak isteyeceği tehlikesine karşı direnç gösterilmesi gerekmektedir. ${ }^{19}$

$\checkmark$ AB: Enerji güvenliği bağlamında bir transit ülke olan Ukrayna'nın güvenliği, Avrupa için önem arz etmektedir. Doğu Avrupa enerji ihtiyacının önemli bir kısmı Ukrayna üzerinden gerçekleşmektedir. ${ }^{20}$ Ukrayna, Doğu Avrupa ile bir entegrasyon sürecine giren $\mathrm{AB}$ için önemli bir ülke konumundadır.

$\checkmark$ Rusya: Stratejik açıdan Kırım, Rus donanmasının üssü olarak önem taşımaktadır. Nitekim Karadeniz Filosu, 1783’te Prens Potemkin tarafindan kurulmuştur. Filonun stratejik konumu ve yarımadaya dayanması, Rusya'nın 2008'de Güney Osetya savaşında Gürcistan'1 yenmesine yardımcı olmuştur ve özellikle bölgedeki Rus güvenlik menfaatleri için de kilit bir noktadadır. ${ }^{21}$ Ayrıca Kırım, aslında Kiev'i isteyen Rusya için ABD'nin korkusunu haklı çıkartacak ölçüde bir test alanı olma niteliğine sahiptir.

Buradaki asıl şüphe ve kriz, Rusya'nın hedefinin Kırım değil de, Kiev olması ihtimalinin altında yatmaktadır. Bu konu sadece AB'yi ya da ABD'yi değil, Japonya ve Çin gibi güçleri de yakından ilgilendirmektedir. $\mathrm{Bu}$ nedenle Kırım bölgesel bir sorun olmaktan çıkarak uluslararası bir

\footnotetext{
${ }^{19}$ A new cold war? Why Crimea should matter to Americans, http://www.usatoday.com/ story/news/politics/2014/03/14/usa-today-capital-download-steven-pifer-ukraine-russia -crimea/6382965/ (Erişim Tarihi: 12.01.2017).

${ }^{20}$ Nataliya Katser-Buchkovska, Why Ukraine is central to Europe's energy security, https://www.weforum.org/agenda/2017/07/why-ukraine-is-central-to-europe-s-energysecurity/ (Erişim Tarihi: 05.10.2017).

${ }^{21}$ Ukraine crisis: Why is Crimea so important to Russia?, http://www.independent.co.uk/ news/world/europe/ukraine-crisis-why-is-crimea-so-important-to-russia-9166447.html (Erişim Tarihi: 12.01.2017).
}

233

Güvenlik Stratejileri

Y11: 13

Say1: 26 
234

Güvenlik

Stratejileri

Y1l: 13

Sayı: 26

soruna dönüşmüştür. Eğer Kırım'ın ilhakı gerçekten meşru olarak kabul görürse, Rusya'nın bu yayılmacı politikasını nereye kadar vardıracağ1 kestirilememektedir. Ya da Rusya'nın izinden hangi ülkelerin gidebileceği, sorunu uluslararası bir endişeye dönüştürmektedir. Rusya ise bu endişeye cevaben, ABD ve Avrupa'yı sadece uluslararası hukuka uyuyormuş gibi davranmakla suçlamaktadır. Batının liberal düzen fikrinin dişında hareket eden Rusya, bu nedenle de sistemin dışına çıkmakta bir mahsur görmemektedir.

\section{Bazı Ülkelerin Kırım Krizine Farklı Politik Ekonomi Yaklaşımları}

AB üyelerinin 2007 yılında Rusya'ya yaptığı yatırımların oran1, 2004 yılına nazaran iki kat artarak 21,1 milyar dolara ulaşmıştır. 2010 y1lı verileri incelendiğinde, AB'nin Rusya'ya en çok makine ve ulaşım ekipmanı (\% 49,6); Rusya'nın ise AB'ye en çok petrol ürünleri (\% 76,3) sattı̆g 1 görülmektedir. AB'nin 2012'deki dış ticaretinde Rusya; ABD ve Çin'den sonra üçüncü sırada yer almıştır. 2013 yılında ise Rusya'nın $\mathrm{AB}$ ülkelerine ihracatı 283,2 milyar dolara yükselmiş; ithalatı ise 134,3 milyar dolar olarak kaydedilmiştir. Rusya'nın AB ülkeleri ile ilişkilerini incelediğimizde, en çok ticaret hacmine sahip olan üç ülkenin sırasıyla Hollanda, Almanya ve İtalya olduğunu görmekteyiz. Öte yandan Rusya'nın petrol ihracatının \% 81'i Avrupa pazarına, \%12'si Asya'ya ve \%6'sı da Amerika'ya gerçekleştirilmektedir. ${ }^{22}$ Daha açık bir ifadeyle enerji; $A B$ ve Rusya arasındaki en önemli bağ olarak ortaya çıkmaktadır ve iki tarafın politik ekonomisinin kalbine yerleşmektedir.

Bu denli ekonomik bir bağımlılı̆̆ın olduğu koşullar göz önüne alındığında, Kırım krizinin devletler arasında sıcak bir çatışmaya dönüşmemesinin iki önemli nedeni karşımıza çıkmaktadır. Bu nedenler, taraflar arasında vazgeçilemeyecek ölçüde karşılıklı bağımlılı̆̆ın söz konusu olması ve $\mathrm{AB}$ içinde farklı çıkar hesaplarının olması şeklinde

${ }^{22}$ Harun Semercioğlu, "Ukrayna Krizi Bağlamında AB-Rusya İlişkilerinin Ekonomi Politiği”, EUL Journal of Social Sciences, 2016, Cilt: 7, Say1: 2, 188-202, s. 192. 
sıralanabilir. Ayrıca çıkan krizle birlikte karşılıklı ekonomik yaptırımlar ve kısıtlamalar ortaya konmuş; hatta bu yaptırımlar $\mathrm{AB}$ devletleri için oldukça yıkıcı olmasına rağmen 2016 yılı sonlarına doğru iki yıllığına uzatılmışır. Ancak Batının yaptırımlarına rağmen elinde bulundurduğu “enerji" kozu, Rusya'nın direnmesine ve geri adım atmamasına olanak sağlamıştır. $A B$, petrolde esas olarak Rusya, Norveç ve çeşitli Orta Doğu ülkelerinden ithalat yapmaya bağımlıdır. Gaz ithalatında ise Rusya, Norveç ve Cezayir AB'nin ana tedarikçileri konumundadır. Ukrayna krizinde Rusya'nın, Ukrayna'nın borcunu ödemediği gerekçesi ile gazda kesintiye gitmesi ise, AB'yi zor duruma sokmuştur. Hatta $\mathrm{AB}$ Komisyonu enerji arz güvenliği ve enerji çeşitliliği politikaları geliştirmelerine sebep olarak gösterdiği iki ana kriz; 1979 petrol krizi ve 2014 Ukrayna krizi olarak karşımıza çıkmıştır. Nitekim Rusya'nın gazı tamamen kesmesi gibi bir senaryoda, $\mathrm{AB}$ 'de neredeyse tüm üretimin duracağı tahmin edilmektedir. Krizin ortaya çıkmasıyla birlikte, "bölgede ben de varım" demekten çekinmeyen ABD; o dönem harekete geçerek önemli bir keşif olan kaya gazı ile AB'nin enerji çeşitliliğine katkıda bulunmak için adımlar atmıştır. Yine de AB'nin kaya gazı ithalatı bugünden yarına gelişecek bir durum olmadığından, AB, Ukrayna krizinde daha temkinli davranmış ve hatta eleştirilere maruz kalmıştır. Ancak temkinli hareket eden AB, Rusya'ya karşı ekonomik yaptırımlar uygulamaktan da geri durmamıştır. Ekonomik yaptırımlar gereği, AB üyesi 28 ülkenin Rusya'ya silah satışı yapması engellenmiştir. Yaptırımlar kapsamında, Rusya'nın petrol ve gaz sektörlerinde kullanılan bazı teknolojileri, $\mathrm{AB}$ ülkelerinden alması kısıtlanmış; Rus kamu bankaları Avrupa'da finans sektöründen de dışlanmış ${ }^{23}$ ve hatta vize kısıtlaması getirilmiştir. Ayrıca Rusya'nın Ekonomik İş Birliği ve Kalkınma Örgütü (OECD) ve Uluslararası Enerji Ajansı (IEA) ile yürüttüğü müzakereler dondurulmuştur. ${ }^{24}$ Ancak $\mathrm{AB}$ içinde $\mathrm{ABD}$ 'nin

${ }^{23}$ AB Rusya'ya yaptırımlart uzattı, http://www.aljazeera.com.tr/haber/ab-rusyayayaptirimlari-uzatti (Erişim Tarihi: 12.01.2017).

${ }_{24}$ Anna Dolya, "L’annexion de la Crimée :leçons pour la sécurité Européenne", Question d'Europe n’382, Fondation Robert Schuman, 22.02.2016, s. 4, https://www.robert- 
236

Güvenlik

Stratejileri

Y11: 13

Say1: 26

en s1k1 müttefiklerinden biri olan Almanya; Rusya ile sahip olduğu ticaret hacmini riske atma konusunda çekimser kalmıştır. Ancak Tablo 1 'de ${ }^{25}$ görüldüğü üzere, yine de Almanya ile Rusya arasındaki ticaret hacmi Kırım sorunun başlangıcıyla birlikte düşüşe geçmiştir.

\section{Tablo 1: 2007-2015 Almanya-Rusya Ticaret Hacmi (milyar dolar)}

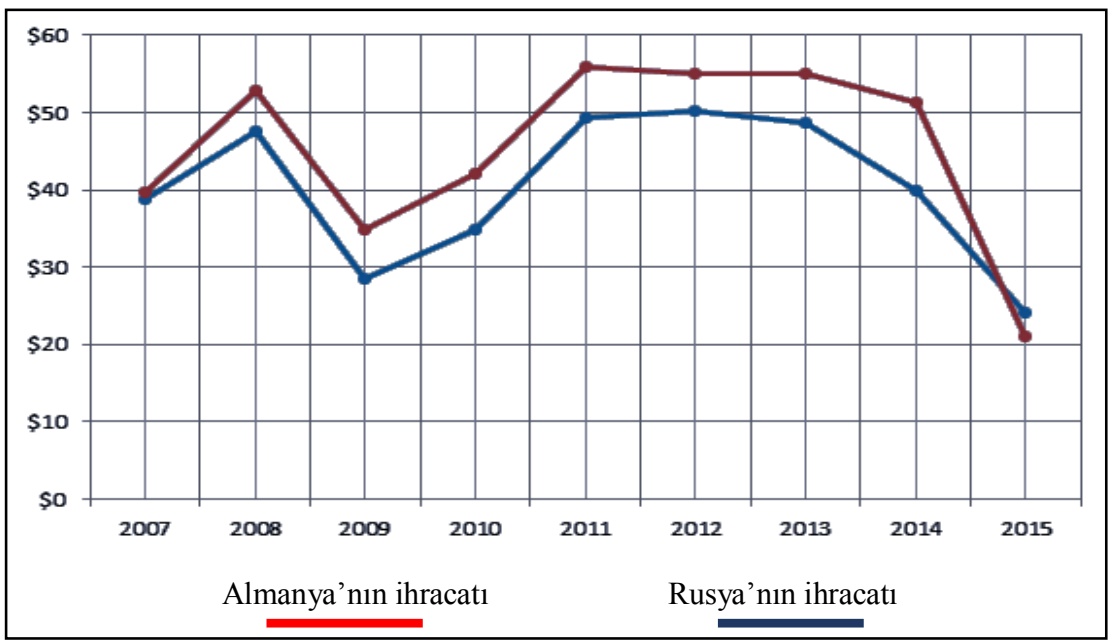

Kaynak: ITC Trade Map- Bilateral trade between Russian Federation and Germany http://www.trademap.org/Bilateral_TS.aspx?nvpm=1|643||276||TOTAL|||2|1|1|1|2|1|1|1|1

Almanya'nın 2014-2015 y1lları arasında Rusya'ya ihracat1 $\% 18$ oranında azalmıştır. 2013-2015 yılları arasında İngiltere'nin Rusya'ya ihracatı \%51 oranında azalmıştır. ${ }^{26}$ Rusya'nın ise AB'ye

schuman.eu/fr/doc/questions-d-europe/qe-382-fr.pdf (Erişim Tarihi: 19.10.2017).

${ }^{25}$ 2007-2015 German-Russian bilateral trade turnover, billion USD. Kaynak: ITC Trade Map, http://www.rusexporter.com/research/country/detail/4366/ (Erişim Tarihi: 18.10.2017).

${ }^{26}$ Konstantin A. Kholodilin and Aleksei Netsunajev, "Crimea and punishment: The impact of sanctions on Russian and European economies", Bank of Estonia Working Papers, 2016, s. 1. 
yaptığı en önemli ihracat kalemi enerji olmuştur. $A B, \% 30$ oranında ihtiyaç duyduğu doğal gazı Rusya'dan ithal ederken; Almanya'nın Rusya'dan ithalat $\% 40$ civarında gerçekleşmektedir. Görüldüğü üzere, devletler arası ilişkilerde özellikle enerji konusunda ciddi bir bağımlılık söz konusudur. Kırım sorununda AB'nin Rusya'ya olan ihracatında kaydedilen düşüşler \%10 seviyesinin üstünde seyrederken; Tablo 2'de görüldüğü gibi, Rusya'nın AB'ye yönelik gerçekleştirdiği enerji ihracatında ciddi düşüşler gerçekleşmemiştir. Çünkü AB'nin Rusya yerine ihracat gerçekleştirebileceği başka pazarlar bulma imkânı söz konusu iken; enerji ithalatı konusunda Rusya yerine başka bir alternatifi çok hızlı bir şekilde hayata geçirmesi mümkün olmamaktadır. Her ne kadar Rusya, Kırım sorunu nedeniyle doğal gazı kısmış olsa da kendi ekonomik gerçekleri nedeniyle sahip olduğu enerjiyi sadece bir koz olarak kullanmakla yetinmiştir. Nitekim Ukrayna krizi ile birlikte enerjinin "diplomasinin ölümcül silahı" 27 olarak ne gibi sonuçlar doğurabileceği test edilmiştir. Sanayileşme ve endüstriyel toplumun vazgeçilmezi olan enerji; sanayileşmenin bir sonucu ve sanayileşmeyle gelen modern dünyanın devamını sağlayan bir girdi olma özelliği ile uluslararası siyasi, iktisadi ve ticari öğelerin ve aralarındaki ilişkilerin değiştiricisi ve dönüştürücüsü olarak karşımıza çıkmaktadır. ${ }^{28}$

\footnotetext{
${ }^{27}$ L'énergie, l'arme fatale de la diplomatie, La Liberté, 8 Haziran 2012, http://www.rts.ch/ docs/histoire-vivante/a-lire/4051758.html/BINARY/li_2012-06-08_hv_10_hv.pdf (Erişim Tarihi: 18.10.2017).

28 Bilgehan Emeklier ve Nihal Ergül, "Petrolün Uluslararası İlişkilerdeki Yeri: Jeopolitik Teoriler Ve Petropolitik”, Bilge Strateji, 2010, Cilt 2, Sayı 3, 59-86, s. 63.
} 


\section{8}

Güvenlik

Stratejileri

Y1l: 13

Say1: 26
Tablo 2: AB'nin (28 üye) Rusya'da enerji ithalatı

Katı Yakıtlar (milyon ton)

\begin{tabular}{|l|c|c|c|c|c|c|c|c|c|c|c|}
\hline \multicolumn{10}{|c|}{ Katı Yakıtlar (milyon ton) } \\
\hline & $\mathbf{2 0 0 5}$ & $\mathbf{2 0 0 6}$ & $\mathbf{2 0 0 7}$ & $\mathbf{2 0 0 8}$ & $\mathbf{2 0 0 9}$ & $\mathbf{2 0 1 0}$ & $\mathbf{2 0 1 1}$ & $\mathbf{2 0 1 2}$ & $\mathbf{2 0 1 3}$ & $\mathbf{2 0 1 4}$ & $\mathbf{2 0 1 5}$ \\
\hline Rusya & 20,2 & 21,4 & 21,5 & 22,7 & 26,2 & 22,8 & 22,9 & 23,0 & 25,9 & 25,9 & 25,8 \\
\hline Kolombiya & 10,2 & 9,7 & 11,0 & 10,7 & 15,2 & 16,9 & 20,7 & 21,7 & 19,6 & 18,8 & 21,3 \\
\hline ABD & 6,5 & 6,7 & 7,9 & 12,2 & 11,8 & 14,2 & 15,7 & 20,6 & 19,5 & 18,3 & 14,0 \\
\hline Avusturalya & 11,2 & 10,3 & 11,3 & 10,2 & 6,5 & 8,9 & 7,7 & 6,6 & 6,7 & 5,6 & 8,1 \\
\hline G.Afrika & 21,4 & 19,8 & 17,4 & 14,4 & 13,7 & 8,2 & 6,9 & 5,7 & 6,0 & 8,7 & 6,9 \\
\hline Endonezya & 6,2 & 7,9 & 6,8 & 6,3 & 6,1 & 4,7 & 4,4 & 4,0 & 2,8 & 3,0 & 3,1 \\
\hline Kanada & 2,7 & 2,4 & 2,6 & 2,3 & 1,2 & 1,7 & 1,9 & 1,5 & 1,6 & 2,2 & 1,4 \\
\hline Mozambik & 0,0 & 0,0 & 0,0 & 0,0 & 0,0 & 0,0 & 0,0 & 0,0 & 0,3 & 0,3 & 0,4 \\
\hline Ukrayna & 1,9 & 1,4 & 1,5 & 2,0 & 1,5 & 1,6 & 2,1 & 1,5 & 1,4 & 1,3 & 0,4 \\
\hline Diğerleri & 19,9 & 20,4 & 20,0 & 19,2 & 17,8 & 20,9 & 17,6 & 15,5 & 16,2 & 15,8 & 18,6 \\
\hline
\end{tabular}

\section{Ham Petrol (milyon ton)}

\begin{tabular}{|l|c|c|c|c|c|c|c|c|c|c|c|}
\hline & $\mathbf{2 0 0 5}$ & $\mathbf{2 0 0 6}$ & $\mathbf{2 0 0 7}$ & $\mathbf{2 0 0 8}$ & $\mathbf{2 0 0 9}$ & $\mathbf{2 0 1 0}$ & $\mathbf{2 0 1 1}$ & $\mathbf{2 0 1 2}$ & $\mathbf{2 0 1 3}$ & $\mathbf{2 0 1 4}$ & $\mathbf{2 0 1 5}$ \\
\hline Rusya & 30,5 & 31,2 & 31,2 & 29,8 & 31,5 & 32,4 & 32,8 & 31,8 & 31,9 & 28,9 & 27,7 \\
\hline Norvec & 15,6 & 14,2 & 13,8 & 14,0 & 14,2 & 12,8 & 11,7 & 10,6 & 11,1 & 12,4 & 11,4 \\
\hline Nijerya & 3,0 & 3,3 & 2,5 & 3,7 & 4,2 & 3,9 & 5,7 & 7,7 & 7,7 & 8,7 & 8,0 \\
\hline S.Arabistan & 9,8 & 8,3 & 6,6 & 6,4 & 5,3 & 5,5 & 7,6 & 8,3 & 8,2 & 8,5 & 7,5 \\
\hline Irak & 2,0 & 2,7 & 3,2 & 3,1 & 3,5 & 3,0 & 3,4 & 3,9 & 3,5 & 4,3 & 7,2 \\
\hline Kazakistan & 4,1 & 4,2 & 4,3 & 4,5 & 5,0 & 5,1 & 5,4 & 4,8 & 5,4 & 6,1 & 6,2 \\
\hline Azerbaycan & 1,2 & 2,1 & 2,7 & 3,0 & 3,8 & 4,1 & 4,6 & 3,6 & 4,5 & 4,2 & 4,9 \\
\hline Cezayir & 3,2 & 2,3 & 1,7 & 2,4 & 1,5 & 1,2 & 2,4 & 2,7 & 3,7 & 4,0 & 4,0 \\
\hline Angola & 1,1 & 0,7 & 1,9 & 2,4 & 2,5 & 1,5 & 2,0 & 1,9 & 2,8 & 3,2 & 4,0 \\
\hline Diğerleri & 29,5 & 30,9 & 32,0 & 30,8 & 28,4 & 30,5 & 24,4 & 24,5 & 21,1 & 19,8 & 18,9 \\
\hline
\end{tabular}

Doğal Gaz (milyar metreküp)

\begin{tabular}{|l|c|c|c|c|c|c|c|c|c|c|c|}
\hline & $\mathbf{2 0 0 5}$ & $\mathbf{2 0 0 6}$ & $\mathbf{2 0 0 7}$ & $\mathbf{2 0 0 8}$ & $\mathbf{2 0 0 9}$ & $\mathbf{2 0 1 0}$ & $\mathbf{2 0 1 1}$ & $\mathbf{2 0 1 2}$ & $\mathbf{2 0 1 3}$ & $\mathbf{2 0 1 4}$ & $\mathbf{2 0 1 5}$ \\
\hline Rusya & 34,6 & 33,0 & 32,1 & 31,2 & 27,6 & 26,8 & 28,3 & 27,8 & 32,4 & 29,7 & 29,4 \\
\hline Norvec & 20,2 & 21,7 & 23,3 & 23,7 & 24,5 & 22,9 & 22,1 & 24,9 & 23,6 & 25,0 & 25,9 \\
\hline Cezayir & 15,0 & 13,6 & 12,7 & 12,3 & 11,9 & 11,7 & 10,7 & 10,8 & 10,1 & 9,7 & 8,8 \\
\hline Katar & 1,3 & 1,5 & 1,8 & 1,9 & 4,6 & 8,1 & 9,6 & 6,8 & 5,2 & 5,5 & 6,1 \\
\hline Libya & 1,4 & 2,1 & 2,5 & 2,4 & 2,4 & 2,2 & 0,6 & 1,5 & 1,4 & 1,7 & 1,7 \\
\hline Nijerya & 2,9 & 3,8 & 3,8 & 3,3 & 2,0 & 3,4 & 3,6 & 2,8 & 1,4 & 1,2 & 1,6 \\
\hline Trinidad\&Tobago & 0,2 & 1,0 & 0,7 & 1,4 & 1,9 & 1,2 & 0,9 & 0,7 & 0,6 & 0,7 & 0,5 \\
\hline Peru & 0,0 & 0,0 & 0,0 & 0,0 & 0,0 & 0,0 & 0,0 & 0,6 & 0,4 & 0,3 & 0,2 \\
\hline Türkiye & 0,0 & 0,0 & 0,0 & 0,1 & 0,2 & 0,1 & 0,2 & 0,1 & 0,2 & 0,2 & 0,2 \\
\hline Diğerleri & 24,5 & 23,5 & 23,1 & 23,5 & 24,8 & 23,5 & 24,2 & 23,9 & 26,0 & 26,0 & 25,5 \\
\hline
\end{tabular}

Kaynak: Eurostat/http://ec.europa.eu/eurostat/statistics-

explained/index.php/Energy_production_and_imports 
Tablo 2'de 2015 yılında, 28 AB ülkesinin katı yakıt ithalatının yaklaşık \% 25,8'inin Rusya'dan gerçekleştiği görülmektedir. Tarihinde özellikle katı yakıtlar arasında en çok kullanılan kömür yönünden zengin olan Avrupa'nın, kömür yataklarının hızla düşmesi, katı yakıt ithalatı konusunda da Rusya'ya bağımlılığı zorunlu hâle getirmektedir. Avrupa'nın kömür rezervleri azalırken, IEA'nın 2020 için çizdiği projeksiyonda, AB'nin kömür kullanımının radikal bir şekilde değişmeyeceği öngörülmektedir. Daha açık bir ifadeyle, AB'nin bir süre daha kömüre olan bağımlığı devam edecektir. Rusya'nın AB'ye katı yakıt ihracatının istikrarına baktığımızda ise, 2010-2013 yılı arasındaki düşüşün dışında, yaklaşık ortalama $\% 25$ oranında seyrettiği görülmektedir.

Ham petrol ithalatında da Rusya, AB'nin birinci tedarikçi ülkesi olma konumundadır. Y1llık bazda ham petrol ithalat payında Rusya'nın ortalama \%2'lik ya da fazla kaybı vardır, ancak $\mathrm{AB}$ ham petrol konusunda ortalama \%29 oranında Rusya'ya bağımlıdır. Düşüşlerin nedeni ise AB'nin çeşitliliğe giderek Nijerya, Azerbaycan ve Kazakistan gibi ülkelerden de y1ldan y1la artan oranda ham petrol ithal etmesidir.

Ukrayna meselesinde bask1 unsuru olarak kullanılan doğal gaz arzında ise henüz Ukrayna meselesinin gündeme gelmediği 2005-2010 yılları arasında, AB'nin doğal gaz ithalatında Rusya'nın payında düşüş gözlemlenmiştir. Rusya'nın payı \%34,6'dan \%26,8'e düşmüştür ve bu 7,8 puanlık bir düşüşe denk gelmektedir. Ancak 2013 'te $\% 32,4$ 'lük paya ulaşan Rus doğal gazında, Kırım sorununun patlak verdiği 2014 yılı ve sonrasında ciddi bir düşüş gerçekleşmemiştir. Görüldügü üzere, her ne kadar Rusya özellikle doğal gaz konusunu Ukrayna meselesinde bir tehdit unsuru olarak gündeme getirmiş olsa da; Rusya'nın tedarikçi ülke çeşitliliğini sağlamamış olması ve aynı şekilde AB'nin de tedarik ülkelerini çeşitlendirmemiş olması, bu karşılıklı bağımlılığın ne kadar derin olduğunu gözler önüne sermektedir. Tarafların içinde bulunduğu alternatifsizlik bugünden yarına aşılacak bir durum olmadığı için karşılıklı ambargoların dozu da Rusya ve AB arasındaki ipleri koparamayacak ölçüde olmaktadır. UPE perspektifinden baktığımızda, ekonomik gerekçelerin siyasal sistemi ve devletler arasındaki siyasi ilişkileri nasıl etkilediği, Rusya ve $\mathrm{AB}$ arasındaki siyasi tutum ve ekonomik ilişkilerin 
240

Güvenlik

Stratejileri

Y11: 13

Say1: 26

korelasyonunun kuvvetinden anlaşılmaktadır. Nihayetinde UPE'nin açıklamaya çalıştığ 1 şey, ekonomik sebeplerden dolayı ortaya çıkan politik sınırlar ve bu politik sınırların ortaya çıkardığı ekonomik durumlardır. Yani başka bir ifadeyle, toplumların çıkar çatışmaları karşısında politikaları seçerken kullandıkları mekanizmalar ekonomik gerekçelere bağlıdır. ${ }^{29} \mathrm{AB}$ 'nin Rusya'ya karşı tutumu da belli sınırlar dahilinde gelişmektedir. Elbette bu, yaptırımların hafifletildiği anlamına gelmemekte; aksine yaptırımlar Rusya'nın hiçbir şekilde geri adım atmaması nedeniyle uzatılmaktadır. En son olarak Avrupa Konseyi, 31 Ocak 2018 tarihine kadar Rusya ekonomisinin belirli sektörlerini hedef alan ekonomik yaptırımları uzatmıştır. ${ }^{30}$

Ekonomik yaptırım etkili olup olmadığı konusunda, Tablo 3'te görüldüğü üzere, AB'nin Rusya'ya ihracatı ekonomik yaptırımların uygulanmasıyla bir düşüş göstermiş olsa bile Ocak 2015 tarihinden itibaren düşüş devam etmemiş; aksine AB'nin ihracat hacminde bir yükseliş gerçekleşmiştir. Kayıp kısa süreli olmuş ve uzun vadeye yayılmamıştır. Bu ihtiyatlı durum da göstermektedir ki, AB'nin aldığ kararlar, Rusya’yı Kırım konusunda caydıracak ölçüde değildir.

${ }^{29}$ Allan Drazen, Political Economy in Macroeconomics, Princeton University Press, 2000, New Jersey, s. 7.

${ }^{30}$ Daniel Gros and Federica Mustilli, The Effects of Sanctions and Counter-Sanctions on EU-Russian Trade Flows, https://www.ceps.eu/publications/effects-sanctions-and-countersanctions-eu-russian-trade-flows\#_ftn2 (Erişim Tarihi: 18.10.2017). 
Tablo 3: Rusya toplam mal ithalat değişimi 2012-2013 (milyon dolar)

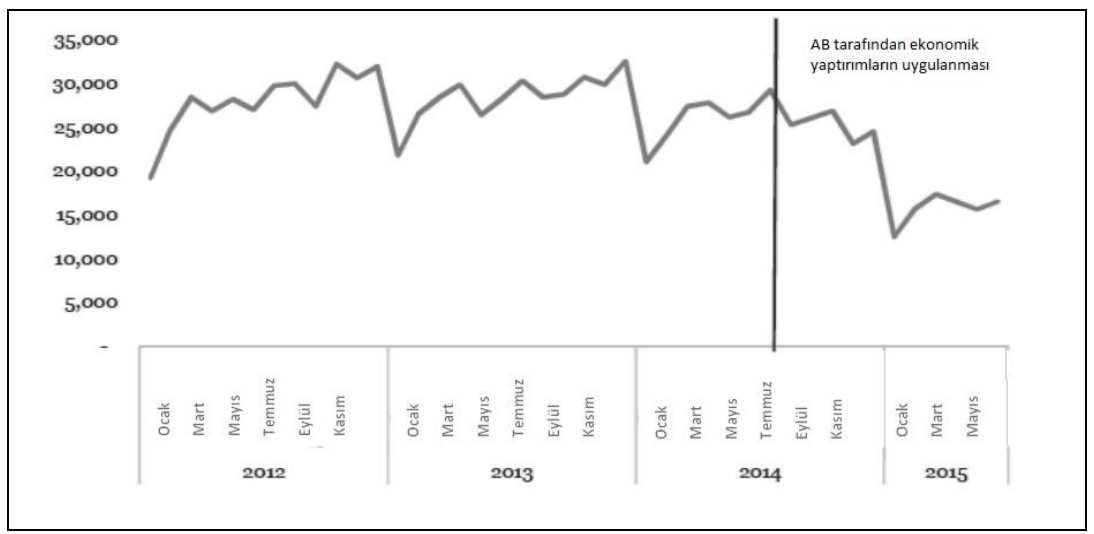

Kaynak: Ödemeler Dengesi Yöntemine Göre Rusya Federasyonu Mal Ticareti / Rusya Merkez Bankası https://www.cbr.ru/Eng/statistics/?PrtId=svs

Tablo 4'te görüldüğü gibi, AB'nin yanı sıra Rusya'nın ticari partneri ABD'nin ve Japonya'nın yaptırımlara verdiği reflekse baktığımızda, her iki ülkenin Rusya'yla olan ticaret hacmi AB'yle olan ticaret hacminin çok altında gerçekleşse de, ABD'nin ihracatı ilk etapta yaptırımların ardından düşüşe geçmiştir. Daha sonra ABD'nin ihracatı artışa geçmiş ve yaptırımlardan önceki seviyesine (Mayıs 2015) ulaşmıştır. Japonya'da ise anlamlı bir değişim gözlemlenmemiştir. Japonya'nın Rusya konusundaki tutumu için Rusya'nın uluslararası tecridini bir firsata çevirme yönünde olduğu söylenebilir. Batı ile uzlaşamayan Rusya, enerji fiyatlarının düşüşünün de etkisi ile yeni pazarlar ve yeni ittifaklar arayışına girmiştir. Çin ile yakınlaşmasının arka planında da bu yatmaktadır. Benzer şekilde, Japonya ile de yakınlaşmaya çalışan Rusya ve Japonya arasında ihtilaflı olan Güney Kuril Adaları'nı çözüme ulaştırmak için bu yakınlaşma bir firsat olarak görülmektedir. ${ }^{31}$

\footnotetext{
${ }^{31}$ Leon Daiske Oberbäumer and Alexandra Sakaki, “A Review of Japanese Periodicals
} 
242

Güvenlik

Stratejileri

Y1l: 13

Say1: 26
Tablo 4: Partner ülkeler bazında Rusya mal ithalatı (yüzde/toplam)

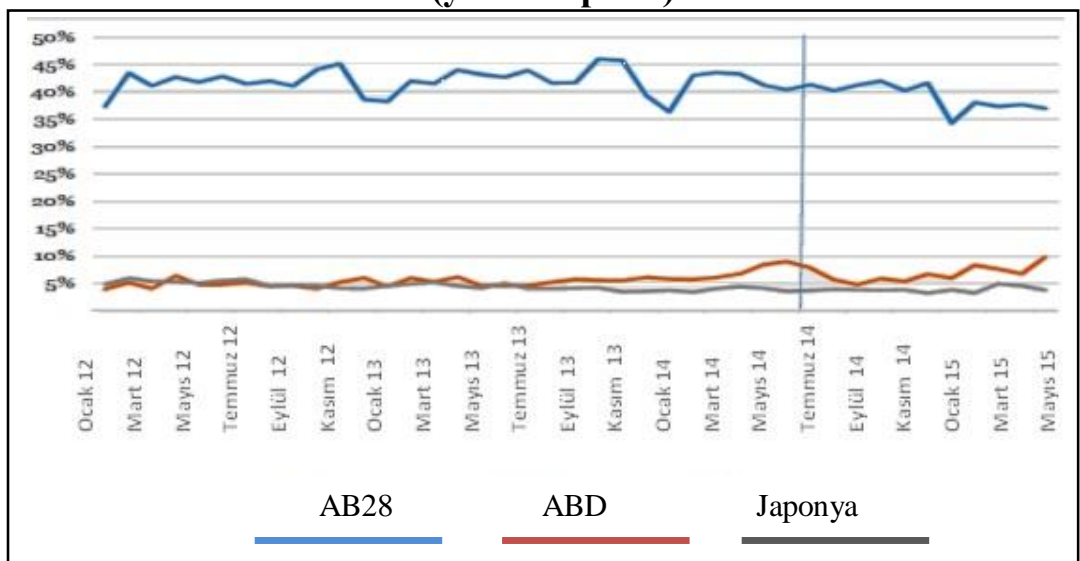

Kaynak: IMF Direction of Trade Statistics (DOTS) http://data.imf.org/regular.aspx?key=61013712

Görüldüğü üzere, AB'nin Rusya için önemli bir enerji pazarı olması; Rusya'nın da AB için bir pazar konumunda olması gerçeği özellikle ekonomik ilişkilerde büyük bir öneme sahiptir. İşte bu gerçek de Kırım konusunu uluslararası politik ekonomi için önemli bir örnek olarak karşımıza çıkarmaktadır. Daha açık bir ifadeyle, Kırım konusunu hem uluslararası hukuki bir kriz olarak, hem de siyasi bir kriz olarak çözümsüzlüğe itmektedir. Uluslararası hukuk normlarını zorlayan, hatta hiçe sayan bir yaklaşım olmasına rağmen, arka planda bulunan politik ekonomi dinamikleri (sorunları) çözümsüz bir şekilde adeta "dondurulmuş" hâlde beklemektedir.

Elbette burada sadece devletlerden bahsedilmemektedir. Devletlerin politik ekonomilerini belirleyen çok uluslu şirketler de önemli aktörler arasında yer almaktadır. Özellikle konu enerji olduğunda devletlerin

and Think Tank Publications in 2014 and 2015”, Stiftung Wissenschaft und Politik, German Institute for International and Security Affairs, 2015, s. 7. 
politik sınırları çok uluslu şirketlerce yönlendirilmektedir. Hatta çok uluslu şirketler enerjiye ulaşma çabasında belki de ön sırada yer almaktadır. Enerjinin kaynağından talep yönüne doğru taşınmasını sağlayan bu çok uluslu şirketlerin enerji temelli diplomaside diğer aktörlere göre daha etkin ve aktif çalıştığı da söylenebilir. Öte yandan, devletlerin ve çok uluslu şirketlerin enerji politikalarında; enerji kaynaklarının güvenliğini, enerjinin ulaşım güvenliğini ve fiyat istikrarının sağlanmasını öncelikli üç hedef hâline getirdiklerini görmek mümkündür. ${ }^{32}$ Başka bir ifadeyle, yine arka planda güçlü ekonomik kaygılar yer almaktadır.

\section{Sonuç}

Uluslararas1 Politik Ekonomi (UPE) denildiğinde, herkesin aklına politik ilişkileri ekonomik alanlarda inceleyen bir bilim dalı gelse de, bu disiplinin inceleme alanına giren konular çok çeşitlidir. $\mathrm{Bu}$ özelliğine bağlı olarak da UPE disiplini içinde kullanılan terimler devamlı olarak gelişme eğilimi göstermekte, böylelikle hem karmaşık, hem de daha detaylı bir inceleme alanına sahip olmaktadır. ${ }^{33}$

UPE açısından çıkarların çatıştığı bir vaka olan Kırım krizi, aynı zamanda uluslararası hukuk bağlamında da vuku bulan bir krizdir. Karşılıklı bağımlılık ilkesi gereğince, Kırım krizinde hayata geçirilen politikalar, atılan ekonomik adımlar ve uygulanan uluslararası hukuk kuralları birbirini zorunlu olarak etkilemektedir. Zira Kırım meselesinde, $\mathrm{ABD}, \mathrm{AB}$ ülkeleri ile Rusya üçgeninde bulunan ve bu ülkelere destek veren/sessiz kalan ülkeler kendi ulusal çıkarlarını ön planda tutarak uluslararası hukuk kurallarına aykırı hareket etmiştir. Sadece sömürge ve işgal altında olan halklara tanınan self determinasyon hakkı Rusya tarafından hukuka aykırı bir şekilde Kırım meselesi için kullanılmış, yapılan eleştiriler için bu hak savunma temeli olarak alınmıştır. Aynı

${ }^{32}$ Aslıhan Turan, “Hazar Havzası'nda Enerji Diplomasisi”, Bilge Strateji, Cilt 2, Sayı 2, Bahar 2010, s. 45.

${ }^{33}$ Arzu Al, Politika-Ekonomi Kesişmesi: Yeni Bir Bilim Dalı Olarak Uluslararası Politik Ekonomi, İGÜSBD,2015, Cilt:2, Say1:1,143-159, s. 147. 
244

Güvenlik

Stratejileri

Y1l: 13

Sayı: 26

zamanda, Kosova meselesinde de self determinasyon hakk1 savunması $A B D$ ve $A B$ tarafından kullanıldığından, Rusya'nın Kırım için aynı hakkın kullanılmasına fazla ses çıkarılmamış ve tepkiler sınırlı kalmıştır.

Kırım meselesinde, yapılan referandum uluslararası hukukun temel ilkelerinden biri olan ülke bütünlügü ilkesine aykırıdır. Ukrayna ülkesinin bir parçası olan Kırım'ın ülke bütünlüğü ilkesine ve Ukrayna Anayasasına aykırı olarak ülkeden ayrılması, uluslararası hukuka aykırıdır. Hatta referanduma katılan çoğunluğun Rus kökenli olması ve katılım oranının düşüklüğü de self determinasyon hakkının kullanımına aykırı olduğuna ilişkin haklı eleştiriler arasındadır. Ancak tüm bu eleştiri ve hukuki tespitlere rağmen, süreç, Kırım meselesinin taraflarının ulusal çıkarlarının öncelikli olduğu konjektürde gerçekleşmiştir. Ukrayna'nın tepkilerine karşılık olarak, Rusya, Ukrayna içinde bulunan Rusların ayaklanmaları tehdidinde bulunduğu göstermektedir. Bunun en somut örneği, Donetsk bölgesinde ortaya çıkan bağımsızlık hareketidir.

Ukrayna, Rusya'nın güvenlik stratejisi ve ulusal gururu konularında büyük önem taşımaktadır. Rusya Devlet Başkanı Putin'in eski Sovyetler Birliği alanına mümkün olduğunca fazla etki yaratması, daha geniş bir tasarımın parçasıdır. Bu amaca yönelik olarak, Rusya; Doğu Avrupa, Kafkaslar veya Orta Asya'da olmak üzere, Sovyetler Birliği'nin eski cumhuriyetlerinin çoğunu içine alan bir Avrasya Ekonomik Birliği (AEB) için planlama yapmaktadır. AEB'deki temel sorun; bu birliğin özellikle NATO'ya ya da AB'ye entegrasyonu engellemesidir. Ukrayna'daki kriz, Batı'nın artık eski bir süper gücün rövanşist içgüdüsü sorunuyla karşı karşıya kaldığını açıkça ortaya koymuştur. Batı; Devlet Başkanı Putin'in kişisel gücünü temel alan kapalı bir rejim ile yüz yüze kalmıştır. Bu rejim, Batılı değerlere ve normlara karşıt olarak tanımlanan istisnai bir Rus kimliğini somutlaştırmak ve savunmak için meşruluğunu sık sık dile getirmektedir. Başka bir deyişle, Batı ile Rusya arasındaki çatışma, Putin'in kendisi tarafından sadece çıkar çatışması olarak değil; aynı zamanda kimlik 
çerçevesinde düzenlenmiştir. ${ }^{34}$ Batının ise elinde iki seçenek söz konusudur: Batı ya uluslararası hukuka uygun hareket edilmesi için ne gerekiyorsa yapılması için çalışacak ya da şu an yaptığı gibi ekonomik kaygılardan ötürü yüzeyde yaptırım uygulayıp Rusya ile ilişkilerini koparmadan devam ettirecektir. Bu ise uzun vadede Rusya'nın istediği küresel sistemin değişmesini kaçınılmaz kılacaktır. Çünkü $A B$ açısından bakıldığında, AB'yi zorlayan ve çözümü güç olan üç durum söz konusudur: Güvenlik kapsamında AB'nin Atlantikçi iş birliği içinde olması ve bu durumun Rusya ile arasında ciddi bir sorun teşkil etmesi, AB'yi Rusya karşısında zora sokan en önemli sorundur. İkinci olarak, $\mathrm{AB}$ içinde bulunan ve Rusya'ya karşı kimlik bağlamında aidiyetini koruyan, görünürde AB'li ama hâlâ Rus olan bir nüfusu bir arada tutma mücadelesidir. Son olarak, AB'nin enerji anlamında Rusya'ya henüz bir alternatif geliştirememiş olması ve bu konuda Rusya'ya bağımlı olmasıdır. ${ }^{35}$ Öte yandan meşruiyet "sosyal bir ilişkidir" ve toplum nezdinde atılan adımların tanınmasına, meşru görülmesine yani kabul görmesine bağlıdır. ${ }^{36}$ Bu bağlamda, uluslararası hukuk çerçevesinde yasallığın yanı sıra, meşruiyet durumunun da sorgulanması uluslararası sistemin toplumsal onay arayışından ileri gelmektedir.

Ekonomik gerekçeler AB'nin Rusya'yla dengeli bir politika yürütmesini zorunlu kıldığından; $\mathrm{AB}$ her ne kadar Rusya ile zit düşmemek için çaba harcamış olsa da, Ukrayna'da meydana gelen fiili durum AB'yi yaptırım uygulamaya zorlamıştır. Daha açık bir ifadeyle, Kırım sorunu, “AB'nin geri adım atamayacă̆ı kadar hassas bir hâl almıştır. Zira Rusya'nın Ukrayna'daki istikrarsızlı̆̆ arttıran eylemleri,

\footnotetext{
${ }^{34}$ Riccardo Alcaro, West-Russia Relatıons In Light Of The Ukraine Crisis, IAI Research Papers, Roma, 2015, s. 13.

${ }^{35}$ Loredana Maria Simionaw, "The European Union and Russia, Cooperation or Competition?", Center for European Studies, Alexandru Ioan Cuza University; The Romanian Academy, Iași Branch, Romanya, 2014, 231-241, s. 235.

${ }^{36}$ Susan K. Sell, "Ahead of her time? Reflections on Susan Strange's contributions to contemporary political economy", George Washington University, 10.01.2014, s. 7, https://www.princeton.edu/ pcglobal/conferences/strange14/sell.pdf (Erişim Tarihi: 19.10.2017).
} 
246

Güvenlik Stratejileri

Y1l: 13

Say1: 26

AB'nin iki hayatî çıkarını doğrudan etkilemeye başlamıştır. Bunlardan birincisi, AB'nin doğu sinırlarında dost ülkeler halkast yaratarak bölgede istikrarı ve barışı tesis etme politikasını tehlikeye düşürmesidir. İkincisi ise Rusya'nın, AB için bir tabu olan Avrupa sinırlarının güç kullanarak değiştirilmesi ilkesini çiğnemiş olmasıdır." ${ }^{, 3}$

ABD tarafinda ise ortaya çıan durum, ABD'nin daha net bir Rusya algısına sahip olmasina hizmet etmektedir. Aynı zamanda, AB'nin Atlantikçi mi yoksa Avrasyacı mı tarafta yer alacağı konusu ABD'nin lehine gelişmiştir. Ukrayna krizi ile ortaya şöyle bir manzara çıkmıştır:

$\checkmark$ Rusya'nın Avrasyacılık politikasında yer alan MoskovaBerlin ekseninin oluşturulmasının önüne geçilerek gelecekte olası ABRusya entegrasyonu da engellenmiştir.

$\checkmark$ Moskova-Berlin ekseninin önüne geçilerek AB'nin Atlantikçi duruşu korunmuştur.

$\checkmark \quad$ Rusya ile yakınlaşmanın sonu gelmiş ve Rus yayılmacılığı yeniden dikkat çekmiştir. Ukrayna krizine kadar gelişen ekonomik ilişkilerin bir çıktısı olarak ortaya çıkan Rusya'ya olan güven yerini güvensizliğe terk etmiştir.

Bütün bu gelişmeler, ABD'nin Avrupa açısından tekrar önem kazanmasına sebep olmuştur. Özellikle Çin'in Rusya'dan yana tavır alması, aynı şekilde Kazakistan'ın da bu işgale destek vermesi, çok kutuplu bir dünya sistemine geri dönüldüğünün bir başka göstergesidir. ${ }^{38}$

Görüldüğü üzere, meşruiyet sorunu ile birlikte yaptırımların yetersiz kalması ya da güçle ilintili olarak etkisizleşmesi, çözümsüzlük ortamı yaratmaktadır. Ortaya çıkan soruna meşruiyet kazandırılamaması ise uluslararası hukuku hedef alan bir tehdit olarak tüm devletleri endişeye sevk etmektedir. Bugün Kırım sorunu günümüzün uluslararası sistemi

37 Ömer Uğur, "Ukrayna Krizi Çerçevesinde Avrupa Birliği'nin Doğu Avrupa'daki İstikrara Etkisi”, SESSION 2B: Bölgesel Çalışmalar, 199-205, s. 201 (alıntılama: Speck, 2014; Larrabee, 2015, s. 24).

38 Kutluk Kağan Sümer, Kırımda Rus İşgalinden Sonra Rusya'ya Karşı Yaptırımların Ekonomik Sonuçları, s. 471, http://www.avekon.org/papers/1227.pdf (Erişim Tarihi: 18.10.2017). 
y1kmaya yönelik sembolik bir düşman olarak algılanmaktadır. Tek kutuplu sistemin artık sürdürülemez olduğu alınan tehditlerden ziyade verilen reaksiyonlarla da net bir şekilde ortaya çıkmaktadır.

2017'nin Temmuz ayında yaşanan yeni gelişmeler dikkatleri yeniden Karadeniz bölgesine çekmiştir. Bu tarihte Donetsk Halk Cumhuriyeti, Ukrayna'dan tek taraflı olarak bağımsızlığını ilan ederek bölgede "Malorossiya" (Küçük Rusya) adlı yeni bir ülke kurulduğunu açıklamıştır ve bu gelişme uluslararası arenada çok yankı uyandırmıştır. Nitekim yaşanan bu olay karşısında Ukrayna sessiz kalmayarak konuyla ilgili sert tepki de göstermiştir. Ukrayna'nın bu tepkisini hem Rusya'nın hem de Rus yanlılarının isteklerine cevap vermeyeceği şeklinde yorumlamak doğru olacaktır. Ayrıca uluslararası düzende yeni bir devlet kurabilmek ve kurulan bu devletin kabul görmesi için uluslararası hukuk kapsamında bazı unsurları yerine getirmek gerekir. $\mathrm{Bu}$ açıklamalar göz önüne alındığında, Küçük Rusya'nın gelecekte bir devlet olarak kabul edilip edilmeyeceğini, Kırım meselesi gibi bitmeyen bir sorun olup olmayacağını ve kazanan tarafin kim olacağını yaşayarak ve bekleyerek öğreneceğiz.

\section{Summary}

The Treaty of Westphalia (1648) established the principles of equality sovereignty of states and formed the working mode of today's international system. International law plays a role as the main actor in order to ensure that states are balanced in the context of interests and power and to bring order to the system. The reference point is legality when international law assesses cases. However, in the international system, if a situation is legal, sometimes it may not be enough to achieve resolution. In addition, "legitimacy" is needed by states and societies. In some cases, it's even in front of legality. In other words, situations which are illegal but which are legitimate in the eyes of states and society, at the very least, bring disagreements out of conflict and lead to a frozen situation. Enforcement of the international system or the use of force is becoming more difficult in situations considered legitimate in the eyes of the international community. This strengthens 
248

Güvenlik

Stratejileri

Y1l: 13

Say1: 26 states which do not act legally. On the other hand, when viewed from the perspective of the International Political Economy (IPE), a consequence of the interaction of economics and politics, states can tolerate illegitimate situations for their own benefit or do not respond as necessary. For example, the Ukrainian crisis, which resulted in the annexation of Crimea in Russia in 2014, emerged as an important case in terms of IPE. The EU and Russia have acted in such a way as not to cause great harm to their interests. The EU imposed sanctions during the Ukrainian crisis, arguing that Crimea illegally participated in Russia. Russia has taken the issue in terms of legitimacy by referring to the Crimean population and the referendum, and marketed it to the world public like this. The Crimean issue, which lies between the "legality" and the "legitimacy" dilemma, offers an opportunity for the EU and Russia to test each other's strength. The EU's dependence on Russia for energy and Russia's biggest energy market is EU, and these two sides are dependent on each other. There is no alternative yet to bring this dependence to a meaningful level. For this reason, especially in the case of the Crimea, the EU has a policy of caution. The economic sanctions of the EU, which has adopted economic sanctions instead of a military sanction, have lost its effectiveness over the years. Russia has not done anything like this, although it has threatened not to perform energy shipment to the EU. As you can see, the Crimean issue has become an arena where the political economy of the countries is struggling over the "legality" and "legitimacy" dilemma. For this reason, the issue of the Crimea remains unresolved and is a frozen matter.

As a result, countries do not allow the international system to work in international law due to political economic reasons. The protection of the power balance causes the states to take shelter under "legitimacy". 
Kaynakça

Kitaplar

ALCARO, Riccard, West-Russia Relations In Light Of The Ukraine Crisis, IAI Research Papers, Roma, 2015.

BALAAM, David and DILLMAN, Bradford, Uluslararası Ekonomi Politiğe Giriş, Adres Yayınları, 2016, Ankara.

BLAY, S. vd., In Public International Law: An Australian Perspective, Oxford University Press, Oxford, 2005.

BRZEZINSKI, Zbigniew The Grand Chessboard, New York, 1997 DOĞAN, İlyas, Devletler Hukuku, Ankara, 2. Bask1, s. 267.

DRAZEN, Allan, Political Economy in Macroeconomics, Princeton University Press, New Jersey, 2010.

GILPIN, Robert, Global Political Economy: Understanding The International Economic Order, Princeton University Press, New Jersey, 2001.

NYE, Joseph S., Soft Power: The Means to Success in World Politics, Public Affairs, New York, 2004.

Makaleler

AL, Arzu, Politika-Ekonomi Kesişmesi: Yeni Bir Bilim Dalı Olarak Uluslararası Politik Ekonomi, İGÜSBD, Cilt:2 Sayı:1, 2015.

ABBAS, Mehdi, L'Économie Politique Internationale entre Théories et Histoire, Recherches Internationaless, 2010, Say1:88.

DOLYA, Anna, L'annexion de la Crimée :leçons pour la sécurité européenne, Question d'Europe $n^{\circ} 382$, Fondation Robert Schuman, 22.02.2016.

EMEKLIER, Bilgehan ve ERGÜL, Nihal, Petrolün Uluslararast İlişkilerdeki Yeri: Jeopolitik Teoriler Ve Petropolitik, Bilge Strateji, Cilt 2, Say1 3, Güz 2010.

İMAMBEYLİ, Vügar, Ülke-İçi Krizden Uluslararası Soruna Ukrayna-Kırım Meselesi, SETA Perspektif, Sayı:36, Mart 2014.

KAVUNCU, Hasan ve DİLAN, Sibel, 21. Yüzyıl Eşiğinde Yeni Çelişkiler: Yeni Krizler Ortamında Uluslararası Siyasal Sistemin Çok Kutupluluğa Doğru Evrilmesi, C.Ü. İktisadi ve İdari Bilimler Dergisi, Cilt: 17, Sayı:1, 2016. 
KHOLODILIN, Konstantin A. and NETSUNAJEV, Aleksei, Crimea and punishment: The impact of sanctions on Russian and European economies, Bank of Estonia Working Papers, 2016.

Y11: 13

NIU, Huei-Chih, The Role of International Economic Soft Law in the

North-South Economic Relations.

OBERBÄUMER, Leon Daiske and SAKAKİ, Alexandra A Review of Japanese Periodicals and Think Tank Publications in 2014 and 2015, Stiftung Wissenschaft und Politik, German Institute for International and Security Affairs, 2015.

POPOVSKİ, Vesselin ve TURNER, Nicholas, Legality and Legitimacy in International Order, Policy Brief, United Nations University, Number 5,2008.

SELL, Susan K., Ahead of her time? Reflections on Susan Strange's contributions to contemporary political economy, George Washington University, 10.01.2014.

SEMERCIOĞLU, Harun, Ukrayna Krizi Bağlamında AB-Rusya Illişkilerinin Ekonomi Politiği, EUL Journal of Social Sicences, Cilt:7, Sayı:2.

SIMIONAW, Loredana Maria, The European Union and Russia, Cooperation or Competition?, Center for European Studies, Alexandru Ioan Cuza University; The Romanian Academy, Iași Branch, Romanya.

SÜMER, Kutluk Kağan, Kırımda Rus İşgalinden Sonra Rusya'ya Karşı Yaptırımların Ekonomik Sonuçları.

TOPAL, Ahmet Hamdi, Kırım İşgali ve Uluslararası Hukuk Krizi (Kırım Krizini Nasıl Okumalı?), DÜBAM, Mart 2014.

TRACTMAN, Joel P., The Crisis of International Law, Case Western Reserve Journal of International Law, Cilt: 44, Sayı:1.

TURAN, Aslihan, Hazar Havzasi'nda Enerji Diplomasisi, Bilge Strateji, Cilt 2, Say1 2, Bahar 2010.

UĞUR, Ömer, Ukrayna Krizi Çerçevesinde Avrupa Birliği'nin Doğu Avrupa'daki İstikrara Etkisi, SESSION 2B: Bölgesel Çalışmalar, s. 201 (alınt1lama: Speck, 2014; Larrabee, 2015, s. 24).

VANEL, Grégory, Le Concept d'Hégémonie en Économie Politique Internationale, Cahier de Recherche-CEIM, Université du Qubec, 2003. 
İnternet

Resolution adopted by the General Assembly on 27 March 2014, http://www.un.org/en/ga/search/view_doc.asp?symbol=A/RES/68/262 A new cold war? Why Crimea should matter to Americans, Stratejileri http://www.usatoday.com/story/news/politics/2014/03/14/usa-todaycapital-download-steven-pifer-ukraine-russia-crimea/6382965/,

12 Ocak 2015.

Ukraine crisis: Why is Crimea so important to Russia?, http://www.independent.co.uk/news/world/europe/ukraine-crisis-whyis-crimea-so-important-to-russia-9166447.html , 12 Ocak 2016.

AB Rusya'ya yaptırımları uzatt1, http://www.aljazeera.com.tr/haber/abrusyaya-yaptirimlari-uzatti , 12 Ocak 2016.

2007-2015 German-Russian bilateral trade turnover, billion USD, Source: ITC Trade Map, http://www.rusexporter.com/research/ country/detail/4366/.

L'énergie, l'arme fatale de la diplomatie, La Liberté, 8 Haziran 2012, http://www.rts.ch/docs/histoire-vivante/a-lire/4051758.html/BINARY/ li_2012-06-08_hv_10_hv.pdf.

Main origin of primary energy imports, EU-28, 2005-2015 (\% of extra EU-28 imports), http://ec.europa.eu/eurostat/statistics.

GROS, Daniel and Mustilli, Federica, The Effects of Sanctions and Counter-Sanctions on EU-Russian Trade Flows, https://www.ceps.eu/ publications/effects-sanctions-and-counter-sanctions-eu-russian-tradeflows\#_ftn2.

Rusya Merkez Bankas1, https://www.cbr.ru/eng/.

IMF Trade Statistics, http://www.imf.org/en/Data.

Cross-Border Merger Control: Challenges for Developing and Emerging Economies, OECD.

Nataliya Katser-Buchkovska, Why Ukraine is central to Europe's energy security, https://www.weforum.org/agenda/2017/07/whyukraine-is-central-to-europe-s-energy-security/. 

